Semina $\square \quad \mathrm{Nr} 14$

Scientiarum 2015

s. $122-129$

DOI: http://dx.doi.org/10.15633/ss.1082

\title{
Poszukiwacz zaginionego celu
}

Thomas Nagel, Mind and Cosmos: Why the Materialist NeoDarwinian Conception of Nature is Almost Certainly False, Oxford University Press, New York 2012, ss. 128

W 2012 roku ukazała się kontrowersyjna książka Thomasa Nagela, której tytuł można przetłumaczyć jako Umyst i kosmos: dlaczego materialistyczna, neodarwinowska koncepcja natury jest prawie na pewno fatszywa $a^{1}$. Thomas Nagel, profesor filozofii i prawa na Uniwersytecie Nowojorskim, jest jednym z najbardziej wpływowych współczesnych amerykańskich filozofów, którego prace obejmuja zagadnienia z filozofii umysłu, etyki i myśli społeczno-politycznej. Po wydaniu wyżej wymienionej książki od razu posypały się burzliwe, w większości negatywne recenzje i komentarze, z których najostrzejsze głosiły upadek niegdyś wielkiego filozofa. Tezy o upadku intelektualnym Nagela o tyle wydają się całkowicie chybione, że idee zawarte $\mathrm{w}$ tej pracy w zasadzie są rozwinięciem rozważań i ostrożnych spekulacji, które od dawna przewijaja się $\mathrm{w}$ jego publikacjach ${ }^{2}$. Ciekawe jest to, że wtedy jego tezy nie wzbudzały aż takich emocji - być może dlatego, że nie były opatrzone tak kontrowersyjnym podtytułem.

W krótkiej, pisanej oszczędnym stylem książce Nagel mierzy się z fundamentalnymi pytaniami, takimi jak powstanie świado-

1 Wszystkie tłumaczenia fragmentów oryginalnego tekstu pochodzą ode mnie [przyp. W. W.].

2 Zob. np. The Psychophysical Nexus, [w:] Concealment and Exposure, and Other Essays, New York 2002, s. 194-235 lub T. Nagel, Widok znikad, Warszawa 1997, s. 100. 
mości i zdolności do obiektywnego poznania rzeczywistości. Nie po raz pierwszy decyduje się on na podjęcie najtrudniejszych i najgłębszych tematów, uważając, że właśnie te najtrudniejsze kwestie są właściwym przedmiotem rozważań filozoficznych. Już wiele lat wcześniej w Widoku znikad pisał, że „małe ambicje nie są schronieniem dla filozofii" ${ }^{3}$. Swoje rozważania rozpoczyna od stwierdzenia, że fizyczny opis Wszechświata jest jedynie częścią prawdy, a jego siła eksplanacyjna jest ograniczona. Współczesna nauka, w której obecnie dominującym paradygmatem jest materialistyczny neodarwinizm (podtrzymujący główne tezy teorii Darwina), nie radzi sobie z wyjaśnieniem takich kwestii jak powstanie świadomości oraz zdolności do obiektywnego poznania świata i dziedziny wartości. Poszczególne rozdziały Nagel poświęca po kolei wyżej wymienionym zagadnieniom, starając się pokazać, dlaczego wyjaśnienia oferowane przez współczesną naukę są niewystarczajace. Krytykując neodarwinizm w powszechnie przyjmowanej wersji materialistycznej - odmawiającej istnienia bytom czy własnościom niematerialnym - Nagel stosuje dwa rodzaje argumentów, które nie zawsze sa u niego przejrzyście rozdzielone.

Po pierwsze, nie negując samego faktu istnienia ewolucji, stara się wykazać, że materialistyczny neodarwinizm jest niewystarczającym wyjaśnieniem rzeczywistości, jako że nie jest w stanie odpowiedzieć na pytanie „dlaczego?”. Nie chodzi przy tym Nagelowi o podanie jakiejś przyczyny bezpośredniej, tylko o metafizyczną odpowiedź na pytanie, dlaczego wystapiło prawdopodobieństwo pojawienia się istot obdarzonych takimi właściwościami jak świadomość i zdolność do abstrakcyjnego rozumowania. Jest to pytanie, które odsyła wprost do metafizycznych spekulacji, bo wiąże się z przekonaniem, że jesteśmy w stanie drążyć w naszych rozważaniach głębiej, niż czynią to nauki ścisłe.

Drugi typ argumentacji wiąże się z silniejszą tezą i jednocześnie jest bardziej kontrowersyjny, albowiem Nagel nie ogranicza się do stwierdzenia, że neodarwinizm nie jest w stanie odpowiedzieć na

3 T. Nagel, Widok znikqd, dz. cyt., s. 15. 
wszystkie pytania związane $\mathrm{z}$ istnieniem takich istot jak ludzie, lecz konstatuje, że twierdzenie, jakoby ciąg przypadków i naturalnej selekcji mógł doprowadzić do powstania niezwykle złożonych istot ludzkich, jest wysoce nieprzekonujace ${ }^{4}$. Widać tutaj podobny sposób myślenia, jaki spotkać można wśród zwolenników teorii inteligentnego projektu, chociaż Nagel odrzuca wyjaśnienie teistyczne. W celu wykazania, że niezbędne jest wzbogacenie teorii ewolucji o dodatkowe elementy, aby stała się koncepcja wiarygodna i przekonująca, dzieli on swoją argumentację na trzy części, które można skrótowo nazwać argumentem ze świadomości, poznania i realizmu etycznego.

Po dosyć rozbudowanych uwagach wstępnych, w których Nagel zarysowuje główne idee książki, i po pobieżnym zwróceniu uwagi na fakt, że nadal nie zostało wyjaśnione, jak powstało życie z materii nieożywionej, filozof przechodzi do pierwszego argumentu, a mianowicie do zagadki fenomenu świadomości, stwierdzając, że czysto fizyczne wyjaśnienie nie jest w stanie ująć subiektywnego, wewnętrznego punktu widzenia świadomego podmiotu. W rozdziale tym Nagel po raz kolejny porusza nierozwiązany problem umysł-ciało, przekonując, że jest to zagadnienie szersze, niż się zwykle zakłada, ponieważ dotyczy naszego rozumienia całego kosmosu i jego ewolucji. Argument odwołujący się do subiektywnego charakteru świadomości można uznać za najmniej kontrowersyjną część książki, ponieważ Nagel już wielokrotnie wcześniej pisał o istnieniu nieredukowalnego, pierwszoosobowego punktu widzenia, wymykającego się zewnętrznym opisom. Prezentowane w tym rozdziale poglądy nie są więc zaskakujące, chociaż wnioski, jakie Nagel wyprowadzi z tych rozważań, będą silniejsze niż w poprzednich publikacjach.

W kolejnym rozdziale zostaje omówione zagadnienie obiektywnego poznania. Nagel zauważa, że problemem dla neodarwinizmu jest nie tylko subiektywny charakter świadomości, ale też nasza zdolność do wychodzenia poza tę subiektywność i odkrywanie

\footnotetext{
4 Zob. T. Nagel, Mind and Cosmos: Why the Materialist Neo-Darwinian Conception of Nature is Almost Certainly False, New York 2012, s. 6.
} 
obiektywnej rzeczywistości, w tym dziedziny logiki i matematyki. Zależy mu na zrozumieniu natury jako systemu, który zdolny jest do wytworzenia istot będących w stanie docierać do prawdy, również tej najbardziej abstrakcyjnej. Nagel przekonuje, że nawet gdyby dało się obronić tezę, iż wyrafinowana matematyka i inne nauki są manifestacjami zdolności, które miały znaczenie dla przetrwania, to pojawia się szereg innych problemów. Można powiedzieć, że refleksje filozofa w tej części książki opierają się na silnym przekonaniu o inteligibilności świata i przypominają znane argumenty z samobójstwa myśli i argument z rozumu, w którym podaje się w wątpliwość przekonanie, że sam dobór naturalny może wyprodukować umysł zdolny do tworzenia obiektywnych teorii ${ }^{5}$. Nagel przedstawia w tym rozdziale wiele cennych uwag i celnych argumentów, chociaż racje te nie będą przekonujące dla zwolenników psychologizmu w logice i matematyce.

Ostatni argument, przedstawiony w kolejnym rozdziale, choć zarysowany już w części poświęconej poznaniu, opiera się na akceptacji realizmu etycznego i trudności w pogodzeniu go z pewnymi aspektami teorii Darwina. Refleksje Nagela w tej materii w dużym stopniu bazuja na artykule Sharon Street A Darwinian Dilemma for Realist Theories of Value ${ }^{6}$, w którym stara się ona wykazać niekompatybilność darwinizmu i realizmu etycznego. Nagel uznaje racje przemawiajace za faktycznym istnieniem owej niekompatybilności, dla niego jest to jednak powód do odrzucenia darwinizmu w wersji materialistycznej, a nie do rezygnacji z realizmu etycznego. Nietrudno zauważyć, że ta część rozważań stoi na jeszcze bardziej chwiejnych podstawach niż poprzednie zagadnienia. Obiektywność w sferze moralności jest jeszcze bardziej problematyczna i częściej atakowana niż możliwość obiektywnego poznania, i jako taka jest słabym argumentem, który zadowolić może co najwy-

5 Por. W. Załuski, Naturalizm jako samobójstwo myśli. (Naturalism as the Suicide of Thought), http://www.academia.edu/7351899/Naturalizm_jako_samobójstwo_myśli_Naturalism_as_the_Suicide_of_Thought_(15. 11. 2014).

6 S. Street, A Darwinian Dilemma for Realist Theories of Value, ,Philosophical Studies" 127 (2006), s. 109-166. 
żej już uprzednio przekonanych. Oczywiście kruchość argumentu i niewielka skuteczność perswazyjna nie muszą oznaczać, że jest on fałszywy.

Powyższe rozważania zawierają zarówno część negatywna, w której Nagel stara się wykazać braki w dotychczasowych wyjaśnieniach nurtujących go zagadnień, jak i część pozytywna, w której analizuje różne koncepcje, aby ocenić, na ile są przekonujące i pomocne w lepszym wyjaśnieniu zmienności świata i powstania człowieka. Jeśli chodzi o odpowiedź na pytanie konstytutywne (z czego składa się rzeczywistość?), przychylnie odnosi się do tak zwanego neutralnego monizmu (panpsychizmu), skłaniając się ku przyjęciu możliwości, że wszystko jest zbudowane z elementów, które w swojej naturze są zarówno fizyczne, jak i niefizyczne, czyli mentalne. Nie uznaje jednak tej koncepcji za wystarczającą i stara się ją wzbogacić o wyjaśnienie historyczne, mówiące o tym, jak możliwa jest ewolucja i wyłanianie się coraz bardziej złożonych struktur. Nagel wymienia trzy możliwości: wyjaśnienie kauzalne, intencjonalne i teleologiczne. Analizując różne warianty połaczenia możliwych rozwiązań konstytutywnych i historycznych, najbardziej usatysfakcjonowany jest koncepcja, która łączy panpsychizm z teleologiczną naturą świata. Naturalistyczną teleologię rozumie w ten sposób, że nieredukowalną częścią naturalnego porządku są zasady rozwoju i wzrostu złożoności, „pęd w kierunku uzyskania pewnych rezultatów"7. Wyjaśnienie kauzalne uznaje za niewystarczajace, a intencjonalne (teistyczne) za niepotrzebne. Jeśli więc przyjmiemy podział na teorie celowościowe w wersji słabej i silnej ${ }^{8}$, to odrzucenie intencjonalności oznacza, że u Nagela występuje ona w wersji słabej.

Można zauważyć, że w rozwiązaniach, które proponuje autor książki, pobrzmiewają echa wielu dobrze znanych koncepcji filozoficznych, np. Barucha Spinozy, Henriego Bergsona czy nawet Pierre'a Theilarda de Chardin, chociaż propozycja Nagela nie jest tożsama z żadną z tych teorii. Oprócz tego wyraźnie nawiązuje on do

T. Nagel, Mind and cosmos..., dz. cyt., s. 93.

8 Zob. M. Heller, J. Życiński, Dylematy ewolucji, Tarnów 1996, s. 113. 
koncepcji arystotelesowskiej, co przejawia się zarówno w pozytywnym stosunku i zaufaniu do zdrowego rozsądku, jak i w postulowaniu istnienia przyczyn celowych $\mathrm{w}$ porządku świata naturalnego (choć oczywiście dla Arystotelesa Wszechświat był niezmienny) ${ }^{9}$. Obydwa elementy sa problematyczne, każde z innych przyczyn. Jeśli chodzi o teleologiczną naturę rzeczywistości, to ze względu na nierozstrzygalność tej hipotezy trudno jest ją oceniać pod kątem naukowym. Nagel sam nazywa swoje rozważania spekulacjami i zaznacza, że znajdujemy się dopiero na początku drogi do zrozumienia owych fundamentalnych kwestii. Co więcej, bierze pod uwagę, iż może się okazać, że brakuje nam aparatu poznawczego potrzebnego do tego, aby kiedykolwiek je zrozumieć. Odmawia jednak poddania się bez walki, ponieważ nie traci nadziei, że może kiedyśs będziemy w stanie dotrzeć do tych głęboko ukrytych prawd. Trudno jest krytykować Nagela za snucie owych spekulacji, zważywszy, że na przykład tworzone przez kosmologów koncepcje wielu światów wydają się równie fantastyczne - a przecież filozofom wolno więcej niż naukowcom, jeśli chodzi o głoszenie poglądów nierozstrzygalnych (wszak nie rozstrzygnięto jeszcze żadnej kwestii filozoficznej). A zatem to nie przeciwko samej tematyce, którą podejmuje Nagel, powinno kierować się ostrze krytyki - problem leży raczej w szczegółowych elementach jego rozumowania. Najpoważniejszy zarzut można wysunać przeciwko dwóm aspektom jego argumentacji. Po pierwsze, wydaje się, że Nagel darzy zbyt wielkim zaufaniem zarówno wspomniany przeze mnie wcześniej zdrowy rozsądek, jak i intuicyjne poczucie, że jakaś teoria jest „nieprzekonująca”. O ile można zaakceptować odwoływanie się do zdrowego rozsądku w sferze moralności - trudno bowiem przyjać koncepcję etyczną sprzeczną ze zdrowym rozsądkiem - to watpliwe jest stosowanie tego samego sposobu myślenia do skomplikowanych teorii naukowych, z których przecież niejedna jawi się jako całkowicie uragajaca zdroworozsądkowym przeświadczeniom. Drugi słaby element w jego argumentacji - zresztą powią-

9 Por. E. Feser, Aristotle, Call your Office, http://www.firstthings.com/web-exclusives/2012/10/aristotle-call-your-office (19.11.2014). 
zany z pierwszym - to częste, ale powierzchowne operowanie pojęciem prawdopodobieństwa, rozumianego potocznie i intuicyjnie. Nagel pragnie stworzyć teorię, w której prawdopodobieństwo powstania świadomych, zdolnych do poznania istot będzie odpowiednio duże. Nie wyjaśnia przy tym, jak duże, ale rodzi się podejrzenie, że nie usatysfakcjonuje go mniejsze niż 50-procentowe. Z tymi dwoma elementami - zdrowym rozsądkiem i prawdopodobieństwem - łączy się kolejny aspekt jego rozważań - pojęcie przypadku, z którym Nagel również sobie nie radzi. Próbuje on zbudować koncepcję, która z jednej strony będzie dopuszczać indeterministyczny model rzeczywistości, a z drugiej strony chce ograniczyć rolę przypadku do minimum - choć nie wiadomo, jakie dokładnie miałoby być owo minimum. Natura według Nagela preferuje wystapienie tych stanów rzeczy, które znajdują się na drodze do osiągnięcia pewnych rezultatów. Nietrudno zauważyć, że przypadek jawi się w tej wizji jako wrogi element, niejako odciagający od właściwego celu i sprowadzający na manowce. Filozof nie chce odwoływać się do boskiej interwencji, jednak w najistotniejszym punkcie zgadza się ze zwolennikami teorii inteligentnego projektu - tak jak oni nie akceptuje roli przypadku w procesie ewolucji, a więc de facto chce pozbawić ja jednego z najistotniejszych elementów. W tym sensie można uznać jego koncepcję za naturalistyczną wersję inteligentnego projektu - interwencja z zewnątrz zastapiona została interwencją wewnętrzna, a w miejsce intencji pojawia się celowościowy charakter rzeczywistości.

W ocenie książki należy wziać pod uwagę, że Nagel nie jest naukowcem, ale filozofem, i że nie jest to rozprawa naukowa. Spekulacje na temat czegoś pierwotniejszego niż materia sięgaja do granicy między tym, co fizyczne, i tym, co metafizyczne - pytanie dlaczego? jest u Nagela pytaniem o sens. W tym świetle zasadność zarzutów, że omawiana książka to czyste spekulacje, jest znacznie osłabiona - aczkolwiek Nagel sam sobie zaszkodził podtytułem, który sugeruje naukowe aspiracje publikacji. Jednak nawet jeśli zaakceptujemy spekulatywny charakter jego rozważań, trudno jest uznać przedstawione argumenty za przekonujące. Można by się zastanawiać nad wysunięciem przeciwko niemu zarzu- 
tu, że sam uległ pokusie - przed która przestrzegał w jednej ze swoich wcześniejszych publikacji - by pragnienie uzyskania odpowiedzi na najważniejsze pytania nie skłoniło nas do przyjęcia zbyt łatwych rozwiązan. Przed tym hipotetycznym zarzutem jednak Nagel częściowo się broni, stwierdzając, że czeka nas jeszcze długa droga do uzyskania ostatecznego rozwiąania tych problemów, a ponadto zdaje się on traktować swoje własne propozycje z nieufnością niewiele mniejszą niż krytykowany przez siebie materialistyczny neodarwinizm. 